\title{
患者-医師関係での認知心理学 患者は医師の説明をどのように理解するのか
}

\section{邑本 俊亮}

〔日内会誌 $100 ： 1700 \sim 1704 ， 2011 〕$

Key words 説明理解, 情報認知, 文脈, 知識, メンタルモデル

はじめに

近年の医療においては，患者をパートナーと 考え，患者参加（あるいは患者中心）の医療が 求められるようになってきた。そのような医療 を進めていく上で重要なのが, 患者一医師間のコ ミュニケーションである，とりわけ，医療の専 門家である医師から患者に対する「説明」は， 医療情報を共有する上で極めて重要な役割を果 たす。

しかし, 実際の医療場面で医師の説明が医師 の意図通り正確に患者に伝わっているという保 証はない. そもそも医師と患者とでは思考や認 識の仕方が異なっており, すれちがいが生じや すい1). ただ, 医師にとって必要なことは, 患者 とまったく同じ思考や認識ができるようになる ことではなく, 患者の情報認知の特徵を理解し, それを知ったうえでコミュニケーションを図る ことではないだろうか.

本稿では, 患者側の説明理解の心理過程に焦 点を当てる.すなわち, 患者が医師の説明をど
のように認知し, 理解しているのかを, 認知心 理学の観点で解説する. 具体的には, まず言語 情報の特性を述べ, 続いて, 情報認知に影響を 及ぼす要因や情報理解過程について考察しつつ, 医師から患者へのコミュニケーションで注意す べき点について論ずる.

\section{1. 言語情報の特性}

\section{1）言語の多義性と曖昧さ}

言語には多義性がある。たとえば，「かんし」 という単語には, 医療器具の鉗子の意味もあれ ば，監視，漢詩，冠詞など，それぞれがまった く異なる複数の意味が存在する. 他にも 1 つの 単語で複数の異なる意味を有するものは多い.

一方, 文のレベルでも多義性は存在する.「患者 は鋭い目つきで病状について話す医師を見てい た」という文は構造上の多義性があり，鋭い目 つきなのは患者であるのか医師であるのかわか らない。また,「学者の話はつまらない」という 文は, 構造上の多義性はないが, つまらないの は「学者がする話」なのか「学者についての話」

東北大学大学院情報科学研究科

Series: For Attending Physicians; Professionalism; Cognitive Psychology for Doctor-Patient Relationship. How do Patients Understand Doctor's Explanation.

Toshiaki Muramoto : Graduate School of Information Sciences, Tohoku University, Japan. 
なのか, 異なる 2 通りの意味が考えられる.

「少し様子を見ましょう」や「お酒を控えてく ださい」などは，医療現場で用いられる可能性 のある表現であるが，いずれも曖昧な言葉を含 んでいる.「少し」とはどのくらいの時間を指す のか,「控える」とはどの程度控えめにしたら良 いのか，人によって解釈が異なるであろう.

\section{2）情報を表現する際の多様性}

ある情報を言語で表現しようとしたとき，そ の表し方は一通りであるとは限らない。たとえ ば，コップに水が半分残っている時「半分もあ る」とも「半分しかない」とも言える.リスク を表現する際にも, 頻度で表現することもでき るが(「1,000 人に 1 人の割合で」), 確率で表現す ることも可能である $(\lceil 0.1 \%$ の確率で」).

こうした表現の違いによって，その情報を受 け取る際の印象が異なってくることがある。た とえば，医師の言葉で「これまで 1,000 人の手術 をしているが, 950 人が 5 年以上生存している」 と「これまで 1,000 人の手術をしているが，50 人が 5 年未満で死亡している」とは同じ事実を 表現しているが，患者にとっては前者のほうが より好ましく感じられる ${ }^{2}$. 生存情報が前面に出 るか死亡情報が前面に出るかで, 印象が変わる のである。こうした現象は，フレーミング効果 と呼ばれている．情報を表現するフレームすな わち枠組みが違うと, その情報の印象が変わり， ひいてはそれによって人々の意思決定さえも変 化してしまうのである.

\section{2. 情報の認知や理解に影響を及ぼす要因}

\section{1）文脈の影響}

情報には，それを取り巻く文脈が存在する。 その文脈が情報の認知をまったく変えてしまう ことがある. 図において, 上の並びは「引力, 重力, 落下」と読めるし, 下の並びは「冠動脈」 と読める. それぞれの並びの真ん中の部分はまっ

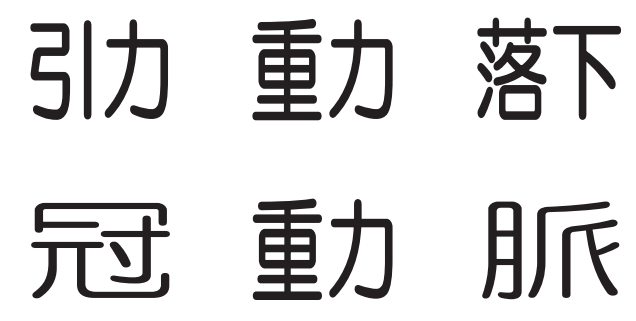

図. 文脈の影響

たく同じ形状をしているにもかかわらず，前後 に配置された文字や文字列によって異なる認知 が生じてしまうのである。これが文脈の影響で ある。

会話においては, 話の流れや会話場面が文脈 である.「かんし」という単語は, 医療現場で医 療器具を話題にしているときには「鉗子」の意 味で用いられることが多いだろうが，防犯用の カメラに関する話の中では「監視」, 古典の授業 の中では「漢詩」, 英文法の授業では「冠詞」と なる.「今日は早いね」は, 早朝に出勤したとき に言われれば文字通りの意味になるが, 大幅に 遅刻したときに言われれば皮肉となる。「僕はウ ナギだ」は，一般的には妙な発言だが, 友人と 食堂でメニューを見ながら順番に注文している という文脈のもとでは，ごく普通の発言となる だろう。

情報は文脈によって意味が決まる。医師は, 患者への説明事項をどんな文脈の中で述べよう とするのか, すなわち, 話の展開や前後関係そ して説明場面などに注意する必要がある。

\section{2）知識の役割}

人間の情報の認知や理解に重要な役割を果た すのが，知識である．たとえば「彼はひどい頭 痛を感じた。彼は保険証を探した」という情報 を聞いて，彼が医療機関へ行こうとしているの だということがすぐにわかる，実際に述べられ ている事実以上のことが知識で補われて理解さ れるのである.ただ，そのことがわかるために 


\section{表 1. 表題がないと理解が困難な文章}

そのやり方は簡単だ. まず, ものをいくつかのグループ に分ける.ものが多くなげればひとまとめでもよい. もし機械がなければ別の場所に行かなければならない が, そうでなければ準備はできたといえる。一度に多く やりすぎてはいけない. めんどうなことが起こってから では遅いのだ。その上, 失敗すると高くついてしまう。 最初は，その手順全体は少し複雑に思えるかもしれない が,すぐに慣れるであろう.その手順がすべて終わると, ものを再びいくつかのグループに分けて整理する. 次 に，それらは適当な場所にしまわれる.結局, それら は再び使用され，その全体のサイクルがくり返される ことになる。とにかく、それは生活の一部なのだ.

(出典) Bransford J D, Johnson M K：1972 上り一部改変

は,「頭痛を感じた時にはどんな目標が生ずるか」 や「その目標を達成するためにどんな行動をと りうるか」, そして「保険証とは何か」などいく つもの知識が必要である。そのような知識がな い人には，彼がとった行動を理解できないはず である。

一般に, よく知らない領域の話を聞いても理 解できないことが多い. 背景知識が不足してい るためである。また，専門家の説明が難解だと 感じられるのは, 専門家は知らず知らずのうち に自分の知識を前提として説明を行ってしまう ため, その知識を共有していない素人には理解 できない内容となっていることが多いからであ る.

ところで, 情報に関連する知識を有していれ ばどんな場合でも理解がうまくいくかといえば, 必ずしもそうではない，表 1 に示す文章を読ん でみてほしい.この文章には表題があるのだが, それを教えられない状態では，内容を理解する ことが困難であろう. 実はこの文章の表題は「洗 濯」である。では，洗濯のことだとわかったう えでもう一度読んでみてほしい. 今度は, 確か に洗濯のことを述べていると理解できたのでは ないだろうか. 洗濯とはどのような作業である かほとんどの人は知っている.つまり文章内容 に関する知識はもっている. しかし, 理解の際 にその知識を記憶の中から引き出してきて利用
できるようにしなければ理解は成立しない。理 解において重要なことは, 関連知識を活性化す ること，そしてその上で情報を捉えることであ る3).

ただし，知識の状態には個人差があり，どん な知識が活性化しやすいかは人によって異なる. したがって，受け手が違えば同じ情報がまった く異なって理解されてしまうということもあり うる.たとえば, 「play」「score」という2つの英 単語が示されたとき, それらを「(スポーツなど で）プレーする」「得点」と理解する人は比較的 多いかもしれない. しかし，音楽活動に携わっ ている人は, それらを「演奏する」楽譜」と理 解する傾向がある. そのような人々は音楽関係 の知識が活性化しやすいからである。同じ情報 でも，それを捉える際に受け手がどのような知 識を活性化するかによって, 情報の意味は変わっ $\tau く る$.

説明を行う際, 医師は, 患者がどのような知 識を持っているか, どのような知識を使って情 報を捉えようとするのかを考えた上で, 情報提 供を行うことが望まれる。

\section{3）受け手の期待}

人間が情報を受け取る際には，その情報に対 して何らかの期待を抱いている場合が少なくな い. そのような場合, 情報の認知・理解は, 期 待によって大きくゆがめられてしまうかもしれ ない.

「土曜日まで雨は降らないでしょう」という表 現は， 2 通りの意味に解釈できる。「土曜日にな るまで降らない,だから土曜日に雨が降る」と いう意味と「土曜日が終わるまで雨は降らない」 という意味である.この多義的な言語表現の解 釈は, 受け手の期待によって変化する可能性が ある.すなわち, 日照り続きで早く雨が降って ほしいと思っている農家の人にとっては前者の 解釈がなされやすく, 土曜日の遠足を楽しみに している小学生にとっては後者の解釈がなされ 
やすいと考えられる ${ }^{4)}$ 受け手の期待に沿った方 向で情報の解釈がなされる可能性があるという ことである。

また，人間はそもそも自分の考えや仮説を確 証してくれる情報を探し求め, そうでない情報 は見過ごす傾向があることが知られている．こ れは確証バイアスと呼ばれている.したがって， 複数の情報が与えられたときには，自分の考え や態度にあった事実のみを受け入れて，そうで ない事実を無視してしまう場合がある。たとえ ば, 死刑の犯罪抑止効果を肯定する研究報告と 否定する研究報告の両方を提示されたとき，死 刑制度に賛成の考えを持っている人は後者より も前者のほうを納得できる証拠として高く評価 し, 死刑制度に反対の人はその逆の傾向がある5 .

医師は，患者がどのような考えや期待を抱い て説明を聞いているのかに注意する必要がある. なぜなら，説明が患者の期待によってゆがめら れ，患者の考えとは異なる説明内容が軽視され たり無視されたりする恐れがあるからである。

\section{4）気分の影響}

人間の認知は，そのときの気分によって影響 を受けることが知られている，たとえば，ポジ ティブな気分の時にはポジティブな内容が記憶 に残りやすく，ネガティブな気分の時にはネガ ティブな内容が記憶に残りやすい，また，情報 の解釈や判断等においても, 気分に一致した方 向での解釈や判断がなされやすい.こうした現 象は気分一致効果と呼ばれている.

たとえば，不安状態にある人はそうでない人 に比べて，曖昧な文の解釈がネガティブになり やすい6). 癌や事故死のようなネガティブな出来 事が起こる主観的確率は, ポジティブな気分で は低く推定され，ネガティブな気分では高く推 定される ${ }^{7}$. 自分の身体症状の知覚や健康促進活 動に対する自己効力感なども気分の影響を受け $ろ^{8)}$.

医師一患者関係において, 医師は患者の気分に
注意すべきであろう。医療コミュニケーション において，患者はネガティブな気分である場合 が少なくない．ネガティブな情報を記憶しやす く, 判断がネガティブになりやすい. 患者の気 分に気をつけながら, 正確かつ十分な情報提供 を行うこと，場合によっては安心感を与える工 夫が必要になることもあるであろう。

\section{3. 情報理解の心理過程}

ここで, 人間の情報理解の心理過程について まとめておこう。我々が情報を受け止める際に は，当該の情報だけではなく，それを取り巻く 文脈情報も同時に受け止めている，文脈の影響 によって, 情報の多義性や曖昧さが解消するこ とも多い.さらに, 知識を活性化することで, 直接的には言及されていない内容を推論で補い, 情報を精緻化している。 また，受け手の期待や 気分などが処理に影響を及ぼし，情報がゆがめ られることもある. その結果, 受け手の頭の中 に構築されるのは, 伝達されている情報そのも のとは異なる，受け手自身の解釈結果である.

これはメンタルモデル(あるいは状況モデル)と 呼ばれている.

情報は, それ自身が意味をもっているわけで はない，情報の受け手がそれを受け取ったとき に意味が作り上げられるのである，つまり，受 け手がそれをどのように受け止め, どのように 理解するかによって, 情報の意味や価值が異なっ てくるということなのである. 医師は, 患者が その説明を聞いたときに頭の中でどのようなメ ンタルモデルを構築する可能性があるかという ことを常に考えながら, 説明を行う必要がある だろう。

\section{4. 伝わるのは説明内容だけではない}

表 2 は，ある高等教育機関で実施された学生 
による授業評価アンケートにおいて, 自由回答 欄に記述された意見の中から抜粋したコメント 例である。もちろん, 実際には「授業がわかり にくい」「説明がむずかしすぎる」のような，授 業内容に対するコメントも多数ある. しかし, ここに挙げたような，授業内容以外のコメント も出てくるのである.ここからわかることは, 学生は授業を受ける中で, 教員の説明内容だけ を受け取っているわけではないということであ る. 教員の気分, 感情, やる気, 態度など, 授 業内容とは関係のない, 教員個人の内面的な部 分まで受け止め, 評価しているということであ る.

医療場面でも同様のことが生じていると考え られる. 伝わるのは説明内容だけではない. そ れは誰しもが経験的には気づいていることであ ろうが, 対人関係において相互の信頼関係を築 く上で非常に重要なことである. 医師のネガティ ブな感情や態度が患者に伝わり, 信頼関係を損 ねてしまっては, もはやどのような説明をも患 者は受け入れなくなる可能性がある。こうした 点からも, 医療コミュニケーション場面におい て，患者が医師からどんな情報をどのように認 知するのかを, 患者の視点で理解しておくこと は大切である.

著者のCOI (conflicts of interest) 開示: 本論文発表内容に 関連して特に申告なし

\section{表 2. 学生による授業評価アンケート における学生の自由記述意見の抜粋}

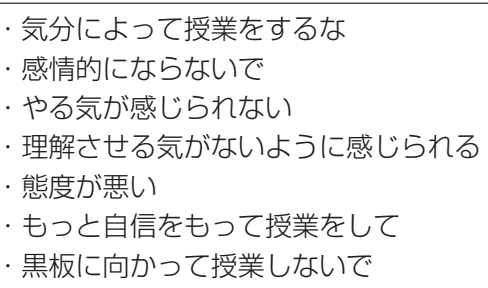

·気分によって授業をするな

·感情的にならないで

·やる気が感じられない

・理解させる気がないように感じられる

・態度が悪い

・もっと自信をもって授業をして

·黒板に向かって授業しないで 